\title{
Research on the Influence of the Capital Structure of the Listed Real Estate Companies on the Performance of the Company
}

\author{
Yinling Liu \\ School of Management, Yulin University, China, 719000 \\ 263050607@qq.com
}

\begin{abstract}
Keywords: Real estate industry; Capital structure; Corporate performance; Factor analysis; regression analysis
\end{abstract}

\begin{abstract}
In the background of the government ' s reform and regulation of the real estate industry, the capital structure of real estate company will face a new round of shuffle, so as to directly influence the operation performance of the company. In order to explore the relationship between the capital structure of the real estate listed company and the company ' s operating performance, the paper selects the Shenzhen A - share real estate listed company as the sample , uses the capital structure and the long - term debt ratio as the explanatory variable, validates the research hypothesis by factor analysis and regression analysis, and analyzes the effect of the capital structure on the operation performance.
\end{abstract}

\section{Introduction}

The real estate industry is a long recovery period of the industry, the demand for capital is huge, capital chain rupture may lead to collapse of Real Estate Company. At present, the Real Estate Company financing channel of our country is narrow, rely heavily on bank loan [1]. in the real estate market demand, rising prices under the condition of optimization of Real Estate Company capital structure, reduce capital the cost is currently China's real estate industry need to solve the problem. The impact of capital structure of listed real estate companies on business performance, explore the development regularity of the real estate industry, improve the management of Real Estate Company, has great practical significance to improve the performance of the company.

\section{An Empirical Analysis of the Influence of Capital Structure of Real Estate Listed Companies on the Performance of Operation}

\section{Sample Source and Selection}

According to the China Commission released the industry guidelines, the 2016 Chinese listed companies in the real estate industry data, in order to ensure the comparability, this paper selects the Shenzhen A shares of the company as the main objects, and to exclude the B-share Companies, finally get the research Sample Firms [2].

Explained variable. Because this study is to explore the real estate listed companies capital structure on the impact of corporate performance. Therefore, in the course of the study, we choose the corporate performance as the explanatory variable of empirical research. The performance of corporate performance is in many aspects, except the ability of the company to operate. It is also shown in the profitability of the company and the liquidity of funds [3]. This study selects the gross sales margin and the net sales interest rate, which reflect the sales profitability. The total asset return rate and net asset return rate, which reflect the profitability of the company's assets, are used as indicators to measure the operating performance[2].

Explanatory variable. The ratio of capital structure choice often as the research field, research object, research objective and method are different. The choice of corporate debt ratio, long-term debt ratio as explanatory variables. The asset liability ratio refers to the ratio of total liabilities to total assets, reflecting the degree of corporate liabilities and long-term solvency [4]. the rate increase will weaken the total assets of the company for the protection of total liabilities, on the contrary will be enhanced. 
Controlled variable. In the process of corporate performance to study the effect of capital structure, the researchers found that the operating performance of the company is not only restricted by the company's capital structure, but also influenced by the size of the company and the company's growth capacity and other factors, the empirical study on firm size of total assets to measure the growth ability of company net profit growth rate. These two factors as control variables.

\section{Sample data}

Table 1 Statistical Table of Relevant Data of Sample Company

\begin{tabular}{|c|c|c|c|c|c|c|c|c|}
\hline $\begin{array}{l}\text { stock } \\
\text { code }\end{array}$ & $\begin{array}{l}\text { profit } \\
\text { margin } \\
(\%)\end{array}$ & $\begin{array}{c}\text { gross } \\
\text { profit } \\
\text { margin } \\
(\%)\end{array}$ & $\begin{array}{l}\text { rate of } \\
\text { return } \\
\text { on } \\
\text { total } \\
\text { assets } \\
(\%) \\
\end{array}$ & $\begin{array}{c}\text { Return } \\
\text { on Net } \\
\text { Assets } \\
(\%)\end{array}$ & $\begin{array}{l}\text { asset-liability } \\
\text { ratio }(\%)\end{array}$ & $\begin{array}{l}\text { long-term } \\
\text { liability } \\
\text { rate }(\%)\end{array}$ & Size(million) & Grow \\
\hline 002146 & 10.98 & 28.52 & 3.00 & 14.03 & 78.6 & 15.96 & $10,287,133$ & 0.75 \\
\hline 00926 & 7.67 & 22.37 & 5.93 & 22.41 & 73.54 & 26.77 & $4,553,750$ & 1.24 \\
\hline 00517 & 9.18 & 29.03 & 1.45 & 3.17 & 54.34 & 10.24 & 793,462 & 0.34 \\
\hline 00615 & 4.48 & 17.75 & 14.26 & 49.72 & 71.31 & 15.13 & 681,726 & 0.46 \\
\hline 00656 & 6.36 & 28.41 & 1.68 & 10.44 & 83.95 & 23.91 & $10,924,916$ & 1.10 \\
\hline 000046 & 25.07 & 48.16 & 2.37 & 18.53 & 87.19 & 31.48 & $11,835,620$ & 1.30 \\
\hline 000616 & 17.96 & 21.69 & 2.61 & 5.17 & 49.43 & 18.23 & 876,374 & 1.16 \\
\hline 002244 & 11.92 & 32.27 & 4.44 & 17.15 & 74.11 & 20.56 & $4,223,022$ & 1.21 \\
\hline 000671 & 7.74 & 25.56 & 2.56 & 13.05 & 80.42 & 23.39 & $7,017,330$ & 1.07 \\
\hline 000031 & 7.40 & 34.26 & 3.02 & 16.39 & 81.58 & 31.26 & $6,127,695$ & 1.00 \\
\hline 000732 & 8.54 & 29.90 & 1.57 & 7.81 & 79.87 & 29.68 & $8,478,163$ & 1.69 \\
\hline 000402 & 14.18 & 30.03 & 3.16 & 11.44 & 72.41 & 19.29 & $11,283,551$ & 1.24 \\
\hline 000736 & 2.50 & 24.44 & 0.71 & 1.93 & 63.44 & 23.25 & 812,694 & 0.38 \\
\hline 000514 & 11.33 & 34.97 & 6.69 & 13.08 & 48.91 & 6.39 & 658,203 & 16.64 \\
\hline 000620 & 6.20 & 26.52 & 1.70 & 8.52 & 80.05 & 20.34 & $3,399,415$ & 0.73 \\
\hline 000540 & 16.99 & 35.44 & 5.64 & 24.11 & 76.61 & 9.59 & $5,540,015$ & 1.63 \\
\hline 000631 & 9.93 & 27.69 & 2.25 & 6.68 & 66.28 & 22.64 & $1,663,940$ & 1.12 \\
\hline 002208 & 4.67 & 25.56 & 1.51 & 6.14 & 75.37 & 32.84 & 978,059 & 1.19 \\
\hline 000863 & 15.32 & 39.57 & 0.91 & 4.06 & 77.64 & 25.94 & $1,347,658$ & 0.72 \\
\hline 000043 & 2.17 & 20.18 & 1.35 & 6.20 & 78.25 & 5.7 & 2173319 & 0.40 \\
\hline 000667 & 12.67 & 36.06 & 4.22 & 11.4 & 62.95 & 23.73 & $1,799,554$ & 1.55 \\
\hline 000797 & 5.36 & 31.47 & 4.40 & 31.76 & 86.16 & 31.38 & 998,914 & 1.12 \\
\hline 000838 & 6.03 & 23.54 & 2.30 & 7.31 & 68.50 & 26.91 & 530,320 & 1.33 \\
\hline 000882 & 16.32 & 31.32 & 1.75 & 3.58 & 51.05 & 18.47 & $1,360,658$ & 2.97 \\
\hline 000002 & 11.79 & 29.41 & 3.58 & 18.41 & 80.54 & 30.79 & $83,067,421$ & 1.16 \\
\hline 002016 & 4.59 & 30.43 & 1.89 & 5.57 & 66.06 & 17.47 & 504,076 & 4.35 \\
\hline 000014 & 4.69 & 20.91 & 2.79 & 6.58 & 57.60 & 7.61 & 87,381 & 0.54 \\
\hline 000006 & 23.93 & 29.13 & 6.19 & 15.88 & 61.05 & 25.08 & $1,317,039$ & 1.87 \\
\hline 000718 & 12.86 & 34.26 & 6.46 & 16.64 & 61.16 & 9.34 & $2,119,286$ & 1.19 \\
\hline 000011 & 14.56 & 39.8 & 6.53 & 13.62 & 52.03 & 23.31 & 437,976 & 0.38 \\
\hline
\end{tabular}

Note : The data is sourced from the NetEase Network

Research hypotheses. The purpose of this empirical study is to test the relationship between the asset-liability ratio, the long-term debt ratio and the operating performance of the company [2], 
based on the existing research results in academic circles, the following hypotheses are put forward:

Hypothesis 1: There is a positive correlation between the asset-liability ratio and the operating performance of listed real estate companies.

Hypothesis 2: The long - term debt ratio of real estate listed companies is positively related to the performance of the company.

\section{The empirical method and model}

Factor Analysis: The factor analysis is used to reflect the relationship between the minority factor variables are related to each other, thus representing a correlation between the original variables and the representative factor, this method can be used to select the factor from the complex relationship in effect is the main explanatory variables in this study, the use of factor analysis on sales gross margin [5]., sales net interest rate, rate of return on assets, net assets return rate of four indicators by factor analysis, so as to obtain the comprehensive index, and use this comprehensive index to reflect the company's operating performance.

Factor analysis: Method is used to obtain the comprehensive index F, and the regression analysis of this index is carried out. The regression relationship between this comprehensive index and asset-liability ratio $\mathrm{D}$, long term debt ratio $\mathrm{D}_{1}$ is established respectively. If the correlation coefficient obtained is positive, then the capital structure has a positive correlation with the company's operating performance, and vice versa, there is a negative correlation between the capital structure and the company's operating performance [2]. To validate assumptions , the following models were constructed :

Modell : $\mathrm{F}=\mathrm{C}+\mathrm{D}+\mathrm{Grow}+$ Size

Model2: $\mathrm{F}=\mathrm{C}+{ }_{1} \mathrm{D}_{1}+{ }_{1}$ Grow $+{ }_{1}$ Size

Empirical analysis

Factor analysis. The use of SPSS software for factor analysis, specific table 2:

Table 2 Total Variance Extraction Table

\begin{tabular}{|c|c|c|c|c|c|c|}
\hline \multirow{2}{*}{ divisor } & \multicolumn{4}{|c|}{ Initial Eigenvalues } & \multicolumn{3}{c|}{ Post - rotation factor extraction results } \\
\cline { 2 - 7 } & sum & variance \% & accumulate \% & sum & variance \% & accumulate \% \\
\hline 1 & 1.857 & 46.42 & 46.42 & 1.855 & 46.386 & 46.386 \\
\hline 2 & 1.626 & 40.64 & 87.06 & 1.627 & 40.674 & 87.060 \\
\hline 3 & 0.383 & 9.58 & 96.64 & & & \\
\hline 4 & 0.134 & 3.36 & 100.00 & & & \\
\hline
\end{tabular}

By Table 2, we can find that the variance of factor 1 is $46.42 \%$, the variance of factor 2 is $40.64 \%$, and the sum of the cumulative contribution rate of these two factors will reach $87.06 \%$, so we can use these two factors as main components.

Establishment of Factor Load Matrix. From table 2 , we can see that factor 1 and factor 2 reflect the main part of the company's performance. So we choose these two factors to calculate the factor load matrix [6]. After rotated, the factor load matrix is shown in the following table 3:

Table 3 Factor load matrix

\begin{tabular}{|c|c|c|}
\hline divisor & divisor 1 & divisor 2 \\
\hline gross profit margin & 0.150 & 0.893 \\
\hline profit margin & -0.001 & 0.905 \\
\hline rate of return on total assets & 0.961 & -0.062 \\
\hline Return on Net Assets & 0.954 & -0.079 \\
\hline
\end{tabular}

As can be seen from Table 3 , in the first main factor, the total asset return rate and the return rate of net assets are larger, so the total asset return rate has the largest contribution to the return rate of the net assets. The two factors mainly reflect the profitability of the assets. In the second main factor, the sales gross profit rate and the sales net interest rate contribute most, so the sales gross profit rate 
and the sales net interest rate contribution are greatest, and the factor mainly reflects the sales profitability.

Table 4 Factor Score Matrix

\begin{tabular}{|c|c|c|}
\hline divisor & divisor 1 & divisor 2 \\
\hline gross profit margin & 0.038 & 0.554 \\
\hline profit margin & -0.043 & 0.555 \\
\hline rate of return on total assets & 0.519 & 0.002 \\
\hline Return on Net Assets & 0.516 & -0.008 \\
\hline
\end{tabular}

According to table 4 the factor 1, factor 2 standardized score coefficient and combined with the original value of the variable can be calculated, the first principal factor and second factor scores of $\mathrm{F} 1$ and $\mathrm{F} 2$, respectively:

$$
\begin{aligned}
& \mathrm{F}_{1}=0.038^{*} \mathrm{X}_{1}-0.043^{*} \mathrm{X}_{2}+0.519 * \mathrm{X}_{3}+0.516^{*} \mathrm{X}_{4} \\
& \mathrm{~F}_{2}=0.554 * \mathrm{X}_{1}+0.555^{*} \mathrm{X}_{2}+0.002 * \mathrm{X}_{3}-0.008 * \mathrm{X}_{4}
\end{aligned}
$$

$\mathrm{X} 1 、 \mathrm{X} 2 、 \mathrm{X} 3 、 \mathrm{X} 4$ is the standard value of the original variable sales gross profit rate, sales net interest rate, total asset return rate and net asset return rate respectively.

The main factor obtained by the above factor analysis obtains the comprehensive performance index $\mathrm{F}$ of each company $\mathrm{F}_{1}$ and $\mathrm{F}_{2}$ :

$\mathrm{F}=(0.46386 * \mathrm{~F} 1+0.40674 * \mathrm{~F} 2) / 0.8706$

\section{Regression analysis}

Select the D asset liability ratio and operating performance index of $\mathrm{F}$ regression analysis, the analysis results are as follows:

Table 5 Analysis of the relationship between D and F

\begin{tabular}{|c|c|c|c|c|}
\hline & Coefficients & standard error & $\mathrm{t}$ Stat & P-value \\
\hline C & 9.5398 & 5.9467 & 1.6042 & 0.1207 \\
\hline D & 0.0614 & 0.0825 & 0.7441 & 0.0454 \\
\hline SIZE & 2.5508 & 5.9346 & 0.4306 & 0.6702 \\
\hline GROW & 0.2548 & 0.3086 & 0.8255 & 0.4165 \\
\hline
\end{tabular}

The regression equation can be obtained from Table 5 above :

$\mathrm{F}=9.5398+0.0614 \mathrm{D}+2.5508$ Size+0.2548Grow

From the data of table 5, we can see that the regression coefficient of asset-liability ratio is 0.0614 , which indicates that under the condition of constant company size and growth ability, asset-liability ratio increases by $1 \%$. The operating performance increased by 614 yuan, and there was a positive correlation between the debt ratio and the operating performance. The regression coefficient of the company size (total assets SIZE) was 2.5508. It means that under the condition that the ratio of assets to liabilities and the growth ability of the company remain unchanged, the total assets increase by 10,000 yuan per year. The regression coefficient of the grow th ability of the company is 0.2548 , which indicates that under the condition that the ratio of assets and liabilities and the size of the company remain unchanged. The growth ability of the company increased by $1 \%$, and the operating performance increased by 2,548 yuan.

The long - term debt ratio D1 and the operating performance indicator F are selected for regression analysis, and the results are as follows : 
Table 6 Analysis of the relationship between $\mathrm{D}_{1}$ and $\mathrm{F}$

\begin{tabular}{|c|c|c|c|c|}
\hline & Coefficients & standard error & $\mathrm{t}$ Stat & P-value \\
\hline C & 11.1599 & 2.3218 & 4.8067 & 0.0001 \\
\hline D1 & 0.1342 & 0.1024 & 1.3111 & 0.0201 \\
\hline SIZE & 4.7823 & 5.8285 & 0.3137 & 0.7562 \\
\hline GROW & 0.2618 & 0.2900 & 0.9026 & 0.3750 \\
\hline
\end{tabular}

The regression equation can be derived from the above table: $\mathrm{F}=11.1599+0.1342 \mathrm{D}_{1}+4.7823$ Size+0.2618Grow

From the data of table 6, we can see that the regression coefficient of long-term debt ratio is 0.1342 , which indicates that the long-term debt ratio increases by one percentage per year under the condition of constant company size and growth ability. The operating performance increased by 1,342 yuan, and the long-term debt ratio was positively correlated with the operating performance. The regression coefficient of the company size (total assets SIZE) was 4.7823 respectively. It means that under the condition that the ratio of assets to liabilities and the growth ability of the company remain unchanged, the total assets increase by 10,000 yuan per year. The performance of the company increased by 47,823 yuan. The growth ability of the company was 0.2618 , which indicated that the ratio of assets and liabilities and the growth ability of the company remained unchanged. For each increase in the company's growth capacity by $1 \%$, the operating performance is increased by $\$ 2,618$, which is consistent with our previous assumptions.

\section{Conclusions and suggestions}

The analysis found that the asset liability ratio, long-term debt ratio and firm performance are positively related. The significant long-term debt rate. Due to the particularity of the real estate industry, the development and construction of a long time, so in the financing process, should reduce the short-term loan increase long-term debt, such debt repayment and development time matching, can reduce the financial risk. But because of China's real estate industry, asset liability ratio is too high, with an average of around $70 \%$, so we must reduce the asset liability ratio, long-term debt ratio can be adjusted. In order to maintain the good development of the real estate industry and avoid financial risks, it is necessary to vigorously develop China's bond the market, the Real Estate Company can issue corporate bonds to obtain long-term funds, actively expand financing channels, but also innovation of financing channels, establish diversified financing channels [8]. In addition, also the operating performance of the company affected by company size, growth ability. The larger the company, the ability to grow stronger, the performance is more significant. For small and medium-sized Real Estate Company, should pay attention to the long-term development of the company, enhance the company's scale, to create better benefits [9].

\section{References}

[1] L.L.Chen. Research on the relationship between Capital structure and Corporate performance of listed Real Estate companies (MS., Yunnan University of Finance and Economics, China 2013) ,P. 25-26.

[2] S.Yang. An Empirical Study on Capital Structure and Operating Performance of Listed Real Estate Enterprises under Macro Policy (MS., Southwestern University of Finance and Economics, China 2013),P. 22.

[3] H.P.Zong. Study on the capital structure of listed companies, the impact on Corporate Performance (MS., Finance and Economics University Of Tianjin, China 2012), P.19.

[4] F.Bai. Research on Financial Strategy and Behavior Based on Life Cycle Perspective (MS., Southwestern University of Finance and Economics, China 2013) ,P. 23.

[5] Y.Zhang: Review on Applied Economics, Vol. 2 (2011) No.00, P.74-77.

[6] F.R.Zhang: Audit and Financial Management, Vol. 34 (2017) No.04, P.40-43. 
[7] B.R.Li,Y.Zhang: Journal of Beijing Technology and Business University(Social Sciences), Vol. 30 (2010) No.03, p.48-52.

[8] T.T.Wang,J.L.Zhang: Modern Business Trade Industry, Vol. 25 (2012) No.13, P. 125-126.

[9] C.L.Li,X.H.Chen: Applied multivariate statistical analysis ( By W.H.Inmon, China 2013),P. 53. 